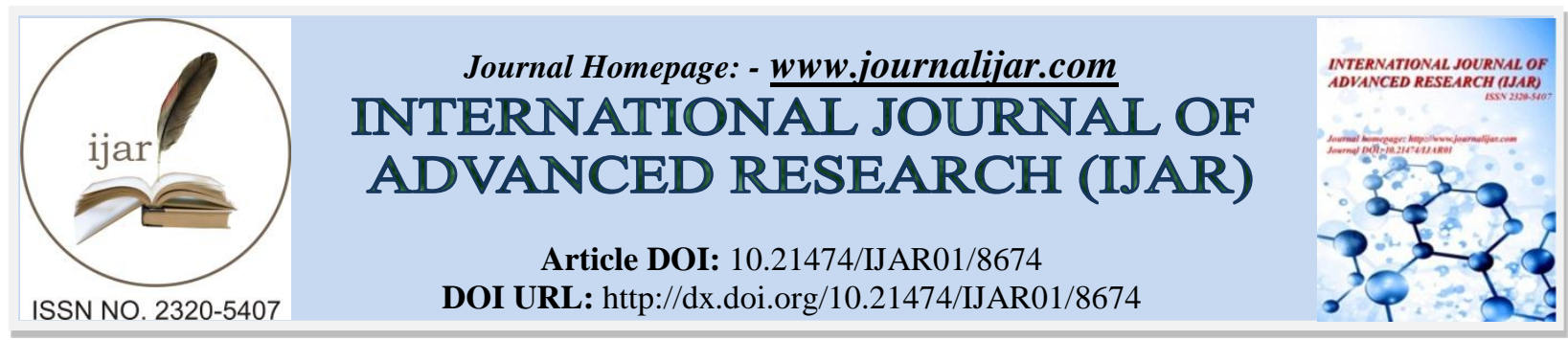

RESEARCH ARTICLE

\title{
EVALUATE THE NEED OF TRAINING AND DEVELOPMENT FOR THE EMPLOYEE SKILLS DEVELOPMENT: A SECONDARY RESEARCH OF PRIVATE BANKING SECTOR IN INDIA.
}

Rashi Tandon ${ }^{1}$ and Dr. Mini Amit Arrawatia ${ }^{2}$.

1. Research Scholar, Jayoti Vidyapeeth Womens' University, Jaipur, Rajasthan, India.

2. Assistant Dean, Jayoti Vidyapeeth Women's University, Jaipur, Rajasthan, India.

\section{Manuscript Info}

Manuscript History

Received: 12 January 2019

Final Accepted: 14 February 2019

Published: March 2019

Key words:-

Skills, Training and Development, Technology, Challenges, Global arena, Re-training and Re-skilling, Training areas, Training Gap identification, Evaluation.

\begin{abstract}
The Banking sector undergoes a sea level changes with respect to the world's economic situation irrespective of the economical status of the country. The challenges it faces shapes the way it behaves in the last few decades. The Banks in general have been well taken forward by the Private sector banks which set the destiny of its own compared to the public sector banks. The Reserve Bank of India or Central Banks in many other countries testifies the same the contribution made by them. The reason behind the sea level change or the challenges cannot be handled by Machine, Money or Materials but it is the Men the prime factor would take care of it, meaning they have been updating along with the changes and challenges it faces. The challenges are very similar like, up-gradation in the technology, people's behavioral change, policy change worldwide, competition and fast changing facts and figures are all the prime contributors for the challenges in the private banking sector. Mumbai is not just one of the states in India where the banks has to function as similar to other places, it I one of the most happening gauged among the top states of cities in the world, therefore the global implication will fall on the Banking players in the state especially private banks, who are considerably fast runners. The challenges have been tackled by the human Resource, named, Employees were provided with the considerable training in two phases, viz., (i) In general and (ii) At a Global standard. The references have considerably contributed to justify and the need for the re-training and re-skilling among the employees of the private banks on all the technical and other areas where the skills to be sharpened. The result of the training well develops the employees professionally along with the organization and the economy as a whole.
\end{abstract}

Copy Right, IJAR, 2019,. All rights reserved.

\section{Introduction:-}

The growing economy of any country does not deny the phrases "Train-up the child when he is young and when he is old he will never depart from it" a very familiar verse from The Bible exactly quotes on the importance of the skill for the development of any sector. When we think about the skill what does it means to us, "The acquired knowledge put into practice for the personal and professional benefits not only on us but the society as well." The 
country's literacy is at a stable growth with respect to the acquiring the knowledge, getting a certificate which authenticates the acquired knowledge but another statistics says that only $15 \%$ of the non-technical education is providing the employment opportunity which is exactly where the skill matches, this statement also proves the rest of the population is remained unemployed since they do not possess the necessary skill which the industry in need of. (Rida Athar, 2015)The Banking sector which is one of the prime sector contributing the growth of the country in all means specifically economic development of the country cannot play a nominal role, the support is given by not the infrastructure of the sector but the prime factor named "Human Resources". Although the banks have been controlled and monitored by the (RBI, 2018)Reserve Bank of India or Central Banks in other countries, it is the skill and the timely decision makes the sector to prosper. Therefore we have understood the efficacy of the training the skills. The above said meaning of the skill has given the clarification that acquiring the knowledge is the First Step followed by practicing the knowledge in the considerable space and ends as a skill where it results in the development of the Industry.

\section{Training and Development}

The phrase cannot be separated and understood at any circumstances whenever there is a training it ends in development if it is done hundred percent. The contribution of all the jargons has got a common goal i.e., "Organizational Growth". The ultimate aim is been achieved through enormous process throughout the professional life of any kind. Banking cannot elude from the process. The bridge between incubation and growth of the organization using the human resources is not very different from the up-gradation of the technology, as the technology grows with respect to machinery a common phenomenon either of the factors of production so is the training and development for the Human Resource as another factor of production. It is clear that the training is always provided for the Human Resources not for the other factors of production, namely, Money, Material or Machinery. The study understands the significant importance of the training and development as whole specifically in the banking sector. The study takes into consideration of all the situations which occurs throughout world in the Banking field. The report emphasizes on the impact of the process and procedure right from the identification of the needs and the coherent skills (British Council, 2017) of the employees as a whole.

\section{1) 1.1 Need for the training}

Why training? Where the need for the training does arises? The common question gives a well known answer that as and when there is a downfall of the sharpness the need arises. Meaning, whenever the result or productivity is measured and found less automatically we know there is a need for the training.

\section{2) 1.2 Identification of the need}

Once the need is sensed and immediately it should be noticed by the experts and when, what, where, to whom are the questions to be answered. The best timing for the training is to be identified? (Banking Governance and Leaership, April 2018) Where the training is to be given? It means that the best pace whether within the same working premises or in some other location. (chahal, 2013)What training is to be given? (Sen, 1984) Whether the routine training or a new one is the need of the hour? Where the employee is lagging has to be identified and accordingly the training is to be organized.

3) 1.3 Training Skills

The Banking Industry has got specified training needs which needs to be considered, $(\mathrm{P}, 1978)$ the list goes as follows

A. Organized Mind: The employee with well organized mind is always accepted, (British Council, 2017)because the banks handles one hundred percent of the public fund, therefore never ever an employee is found with any sort of an unorganized mind, he/she should be well pleasing with the customer or anyone whom he comes across.

B. Good Communication Skills: (British Council, 2017)The employee should be very good in communication skill, reason since he deals with the money a small wrong or miscommunication will definitely affect the entire bank not only of that branch but almost all the branches which is spread across.

C. Accuracy \& Efficiency: (Rida Athar, 2015) The basic skill every bank employee should possess.

D. Mathematical \& Analytical Ability: The beginning and until the end of the day every employees deal with numbers so Maths and accuracy in maths plays a vital role. 
E. Co-operative \& Friendly Personality: Everyday many are the visitors of all sort, someone very cool, someone very aggressive, someone in urgency and emotional, It is very difficult to define the traits of everyone who visits the bank, So, this skill is very essential.

F. Quick Learner: Obviously none has time to repeat therefore he/she should be a quick learner.

G. Leadership: (Banking Governance and Leaership, April 2018) The bank employees will always have a ob rotation, meaning no one will do a permanent job as a teller or as a customer front throughout their career. Everyone will play every role within a stipulated time interval.

H. Management: (Hudgins, 2012)The basic managerial skill always needed as everybody plays every role in a specified period of time.

I. Alert \& Awareness: The situation and the latest implementation of the technology always wander the alertness and awareness of the employee in the bank premises during the office hours.

J. Honesty \& Integrity: The very essential skill which all the bank employs should possess, that is the reason why this skill is treated as high priority.

4) 1.4 Effectiveness of the training

Once the training is provided it needed to be measured on its effectiveness on the employee as well as on the business growth, here in the banking sector.

B. 2. The Indian Banking Industry:

So far the paper has been mentioning about the basic skills needed for a bank employee and of-course it is also applicable for the other sectors of the business as well. Now we need to understand the state of the Banking sector at this juncture.

The RBI has revealed as per BSR-1 \& 2 returns have been revised with effect from March 2002 as a Survey in line with policy changes and developments in the banking sector and also with a view that to have uniform coding system for occupation/activity classification as per the National Industrial Classification (NIC), 1998.

\section{The following are the significant features of the revision:}

The 'Private Sector' banks comprises Private Corporate Sector and Private Sector-Others. (Pooja Antil, 2017)

Private Sector-Others includes the following:

1. Partnership/Proprietary Concerns and Joint Families

2. Self Help Groups and NGOs

3. Associations, Clubs, Trusts and Groups.

C. The grouping of banks is as under: (Pooja Antil, 2017)

(a) State Bank of India and its Associates

(b) Nationalized banks

(c) Foreign banks

(d) Regional rural banks

(e) Other scheduled commercial banks.

\section{3. The Ten Best Global Banking Practices}

The Post-GFC financial sector reforms are set to reshape banking practices, which is leveraging on technology advances in financial services and spurred by (Chandulal, 2016)competitive disintermediation by non-banks, capital markets, electronic trading platforms, and changing demographics and customer profiles. According to the (GOI, 2017-18) Report on Trend and Progress of Banking in India 2017-18It is found useful on all aspects that to track the key standard setting benchmarks that have evolved over a period of time and how they have influenced banking practices in jurisdictions for which authoritative information is available.

A. Capital Buffers: The new norm which has been brought into practice in the banking sector is Basel III standards which has come into effect in the year 2009, prescribes (i) minimum regulatory capital requirements, (ii) capital conservation buffer, (iii) countercyclical capital buffer and (iv) Leverage ratio. There has been an animated 
debate on the adverse impact of these capital requirements on bank lending versus the importance of these buffers in minimizing the taxpayer funded bailouts. Meanwhile, banks are aligning their capital positions with these norms. In several jurisdictions which also include the India, national regulators have set CRAR at a level slightly higher than the (Koundal, 2012)Basel minimum as a prime note.

B. Liquidity Buffers: The second important practices towards the end of 2010 is the Basel Committee on Banking Supervision (BCBS) recommended two liquidity standards - (i) the liquidity coverage ratio (LCR)8 and (ii) the net stable funding ratio (NSFR)9. The main objective of LCR is to reduce banks' reliance on short-term, and volatile funding sources that may be subject to rollover risks, and also while the aim of NSFR is to build liquidity resilience over from the medium to long term. Whereas the LCR in India is being phased in during 2015-19, the Reserve Bank has well notified that the NSFR guidelines will come into effect from April 01, 2020, which is not a long way. As f now Indian banks maintained an LCR of 139 per cent as at end-June 2018. But the Banks in the Euro area as of Q2:2018, maintained an LCR of 141 per cent which is slight high comparatively.

1) C. Asset Quality: The third important one states that there is considerable heterogeneity in prudential frameworks governing (Singh, 2016)NPA recognition, classification and measurement. The recent guidelines on prudential treatment of problem assets (PTA) (BCBS, 2017) complement the existing accounting and regulatory framework for the asset categorization, which is mandate. But in the case of Ireland after the 2008 crisis, the regulatory tightening became inevitable to arrest the rise in NPLs. Whereas, in Romania a multi-faceted approach has been adopted: encouraging banks to dispose of non-collateralized and fully provisioned NPLs; (Koundal, 2012) recognizing the market value of collaterals; and conducting stricter on-site inspections. The State empowered asset management companies (AMCs) is to reduce NPLs have been adopted by many Asian countries such as Thailand, Korea and Japan etc., The Indian context by the Reserve Bank has adopted a multi-pronged strategy of recognition, provisioning and resolution to address the NPA problem. This enactment of the Insolvency and Bankruptcy Code (IBC) has strengthened the NPA resolution process considerably well.

2) D. Profitability: Banks need to maintain a minimum profitability (Singh A. K., 2015) to reward equity holders as owners, while they were building adequate reserves against unforeseen contingencies. In the experience of our country, the following general tendency has been adopted as a multi-dimensional approach to the analysis of (RBI, 2018) profitability indicators such as NIM, RoA and RoE.

3) E. Risk Management: The Efficient risk capture is the first line of defense against build-up of vulnerabilities among the banking sectors globally. (Hudgins, 2012)To strengthen regulation, Basel III has been revised and standardised the approaches for (i) credit risk, (ii) market risk and (iii) operational risk under pillar 1, which is also along with a redrawn boundary between the trading book and the banking book etc. The pillar 2 of Basel III reforms, guidance for management of interest rate risk in the banking book has been published in 2016. Therefore BCBS jurisdictions are working to implement standards for interest rate risk in the banking book, which has a deadline of implementation in 2018. But as of September 2018, countries like Argentina, Japan and Indonesia have published the final rules. In the case of India the draft regulation has been perfectly published. The BCBS deadline for implementation of revised approaches to risks is set in the year 2022.

4) F. Harnessing FinTech: The Technology-enabled innovation in financial services, commonly known as FinTech, actually challenges the traditional brick-and-mortar banking model by lowered costs and vastly expanded the financial reach. (G. Siva Krishna, 2012)The Mobile banking, P2P lending, aggregators and the like have been changed the way financial services are being offered, but it is very critical to be mindful of the embodied risks.

5) G. Investing in Cyber-security: The Recent cyber attacks across the globe highlights the severity of cyber risks being faced by the banks. (FAROOQI, 2017) The Studies have shown that cyber risk could have potential implications for financial stability. The Guidance on cyber resilience for financial market infrastructure (Committee on Payments and Market Infrastructures, 2016), provides general directions to assess preparedness of cyber resilience capabilities. The Regulators which is recognized the importance of managing cyber risks among regulated entities and have rolled out approaches to enhance banks' cyber security frameworks. The Jurisdictions such as European Union have published the guidelines for assessment of Information and Communication Technology (ICT) risk in the year 2017, which is in addition to setting up a risk reporting framework. The UK did not leave it aside and it has developed CBEST in the year 2015, which is a supervisory toolkit for testing the cyber resilience of individual institutions. World-wide including US Federal Financial Institutions Examination Council (FFEIC) too has developed a cyber security assessment tool in the year 2015 to assess cyber security risks and preparedness of 
institutions. (SHARMA, 2010) Therefore a cyber-incident reporting framework of ECB has been operational since 2017. In the month of June 2016, the Reserve Bank also put in place a cyber security framework for all banks.

6) H. Financial Inclusion, Financial Literacy and Consumer Protection: The Banking practices with respect to financial inclusion have differed from one country to another country. The country Kenya benefited through mobile banking, bundling of services, and digital financial services whereas, Brazil implemented a correspondent banking model to target the under-banked. The countries like India, Indonesia and (Vershinina, 2017) Russia have introduced no-frills accounts for low income customers. The Microfinance intuitions have helped Bangladesh in financial inclusion in a well manner. According to Ahamed and Mallick, 2017 a correctly implemented financial inclusion strategy has been shown to improve bank stability and growth. Also, as a Best practices, the inclusion needs to be complemented by financial literacy and customer protection. (British Council, 2017)The country like India leads the BRICS in many important parameters. It has caught up with China, with an 80 per cent of its adult population having access to bank accounts in the year 2017. The gender gap in access to banking has been shrunk sharply over the last three years due to various reasons. The Prime Minister's introduction of Jan Dhan Yojana (PMJDY) has been a game changer for financial inclusion is a belief.

7) I. Strengthening Corporate Governance: The Best practices aimed at strengthening the corporate governance have been mooted in various forms, (Banking Governance and Leaership, April 2018) which is including in multilateral agencies such as the BIS, the IMF, OECD and the World Bank as well as by national authorities. The countries core principle has been that the ultimate responsibility should rest with the board of banks which should be qualified, individually and collectively by the central banks itself. The corporate governance of the bank should be adequately transparent to all its (i) shareholders, (ii) depositors, (iii) other relevant stakeholders and market participants as well. It is understood that there are significant differences in the legislative and regulatory frameworks across countries. The EU has issued the CRD IV directive in the year 2013 requiring member states to ensure effective oversight by the management body, with the due consideration given to knowledge, qualifications and skills. The country like New Zealand also requires that a strict majority of the bank's board must be nonexecutive, and at least a half of the board must be independent. But in India, the Reserve Bank has been developing and strengthening corporate governance practices in banks since the early 2001, including 'fit and proper' criteria for the

directors of banks, the processes for collecting information and exercise of due diligence, which is including scrutiny of declarations made by the bank directors. The Banks also should have independent committees like (i) audit committees and (ii) risk committees to evaluate. A Banks Board Bureau has been set up by the government in the year 2016 with a view to improving the governance in PSBs almost globally.

8) J. Accounting Standards: The last (Dr.V.Radha, 2012) Best practices Worldwide, banks follow a globally accepted and consistent set of the accounting principles under the new International Financial Reporting Standards (IFRS). With effect from $1^{\text {st }}$ January 2018, the implementation of IFRS9 has begun then, with a forward-looking approach embodied in an expected loss model moved forward, it is replacing the IAS39 based on the incurred loss model. But Among the G20 economies, 15 of them have adopted the use of IFRS standards for all or most companies, with notable exceptions being Japan, whereas, IFRS standards are voluntary, and the US where domestic securities issuers follow national standards, and China, India and Indonesia, which have been adopted national standards modeled along the lines of IFRS. In contrary, On a more global scale, 143 jurisdictions have begun using IFRS for or all or most of domestic publicly accountable entities (listed companies and financial institutions). The $1^{\text {st }}$ April 2019 all the banks in India are expected to transition to Indian Accounting Standards (IND-AS), which are said to be IFRS-converged. All the Nonbanking financial companies have already transitioned to the new accounting standard. 
E. 3. The strong standing challenges of the Banking Industry globally:

F. (Figure A). The importance of protecting against internal and external threats is clear in banks' 2018 priorities

\begin{tabular}{|c|c|c|c|}
\hline & 2018 priorities: all banks & 2018 priorities: G-SIBS & 2017 ranking: all banks \\
\hline Enhance cyber and data security & $89 \%$ & $90 \%$ & \\
\hline Implement a digital transformation program & $85 \%$ & $82 \%$ & \\
\hline Recruit, develop and retain key talent & $83 \%$ & $82 \%$ & \\
\hline Gain efficiencies through technology adoption & $82 \%$ & $82 \%$ & \\
\hline Invest in technology to reach and service customers & $81 \%$ & $86 \%$ & \\
\hline Manage reputational, conduct and culture risks & $79 \%$ & $82 \%$ & \\
\hline Comply with consumer regulations & $78 \%$ & $77 \%$ & \\
\hline Optimize the balance sheet & $78 \%$ & $82 \%$ & \\
\hline Manage the threat of financial crime & $78 \%$ & $76 \%$ & \\
\hline Meet compliance and reporting standards & $77 \%$ & $67 \%$ & \\
\hline Improve risk management & $77 \%$ & $73 \%$ & \\
\hline
\end{tabular}

The above picture depicts very clearly the priorities among the banking industries globally and the stand what every (Foreign Banks 2015-18, 2018) country has to take in view of training their employees so that to develop and grow further.

(Figure B) Ratio of Non-performing Loans and Advances (NPL Ratio, Percent) 


\begin{tabular}{|c|c|c|c|c|c|c|c|c|c|c|c|}
\hline Country/Region & Sep 15 & Dec-15 & $\operatorname{Mar}=16$ & Jun-16 & Sep $\cdot 16$ & Dec-16 & $\operatorname{Mar}-17$ & Jun 17 & Sep $\cdot 17$ & Dec-17 & $\operatorname{Mar} \cdot 18$ \\
\hline Austria & 7.4 & 6.9 & 6.5 & 6.0 & 5.8 & 5.1 & 4.6 & 4.3 & 4.0 & 3.7 & 3.4 \\
\hline Belgium & 3.9 & 3.9 & 3.7 & 3.6 & 3.4 & 3.2 & 2.9 & 2.8 & 2.7 & 2.6 & 2.4 \\
\hline Cyprus & 50.0 & 48.9 & 48.5 & 47.4 & 46.7 & 45.0 & 43.8 & 42.7 & 40.6 & 38.9 & 38.9 \\
\hline Estonia* & n.a. & n.a. & 1.6 & 1.5 & 1.4 & 1.3 & 1.3 & 1.3 & 1.3 & 1.7 & 1.9 \\
\hline Finland & 1.4 & 1.6 & 1.5 & 1.5 & 1.5 & 1.6 & 1.6 & 1.7 & 1.6 & 1.5 & 1.3 \\
\hline France & 4.2 & 4.0 & 4.0 & 3.9 & 3.7 & 3.7 & 3.5 & 3.4 & 3.2 & 3.1 & 3.2 \\
\hline Germany & 3.1 & 3.0 & 2.9 & 2.6 & 2.5 & 2.5 & 2.4 & 2.2 & 2.1 & 1.9 & 1.7 \\
\hline Greece & 43.5 & 46.2 & 46.6 & 46.9 & 47.1 & 45.9 & 46.2 & 46.5 & 46.6 & 44.9 & 45.3 \\
\hline Ireland & 19.6 & 17.8 & 15.1 & 14.6 & 14.4 & 12.3 & 11.5 & 11.8 & 11.4 & 10.5 & 8.2 \\
\hline Italy & 16.9 & 16.8 & 16.6 & 16.4 & 16.4 & 15.3 & 14.8 & 12.2 & 11.8 & 11.1 & 10.8 \\
\hline Latvia & 4.9 & 4.0 & 3.9 & 3.7 & 3.6 & 3.2 & 2.9 & 2.7 & 2.6 & 2.3 & 4.0 \\
\hline Lithuania & 5.5 & 5.1 & 4.9 & 4.5 & 4.1 & 3.8 & 3.7 & 3.3 & 3.1 & 2.8 & 3.0 \\
\hline Luxembourg & 1.4 & 1.1 & 1.2 & 1.0 & 1.2 & 1.1 & 1.1 & 1.1 & 1.2 & 0.7 & 0.8 \\
\hline Malta & 6.3 & 6.2 & 5.6 & 5.4 & 4.6 & 4.4 & 4.2 & 3.9 & 3.6 & 3.5 & 3.5 \\
\hline Netherlands & 2.8 & 2.8 & 2.7 & 2.7 & 2.6 & 2.5 & 2.4 & 2.5 & 2.4 & 2.3 & 2.2 \\
\hline Portugal & 18.8 & 19.6 & 19.8 & 20.1 & 19.8 & 19.5 & 18.4 & 17.5 & 16.6 & 15.2 & 13.6 \\
\hline Slovakia & 5.2 & 5.2 & 5.0 & 4.8 & 4.6 & 4.2 & 4.1 & 3.8 & 3.6 & 3.4 & 3.3 \\
\hline Slovenia & 24.6 & 21.5 & 19.7 & 19.2 & 16.3 & 14.4 & 13.5 & 13.3 & 12.6 & 10.5 & 9.3 \\
\hline Spain & 6.8 & 6.3 & 6.3 & 6.0 & 5.9 & 5.7 & 5.5 & 5.4 & 4.8 & 4.5 & 4.5 \\
\hline European Union & 5.9 & 5.7 & 5.6 & 5.4 & 5.3 & 5.1 & 4.8 & 4.5 & 4.2 & 4.1 & 3.9 \\
\hline
\end{tabular}

*: Data is not disclosed because it was reported for less than three institutions.

Note: Deep red depicts the highest NPL ratio for a country over time whereas deep green reflects the lowest NPL ratio for a country over time.

Source: European Banking Authority.

The above picture explains yet another challenge is being faced by the Banking Industry (Foreign Banks 2015-18, 2018) world-wide, but here on select economies of countries. The employees need to be trained towards the above consequences so that they will be world standard in execution.

New Challenges with Globalization and the Impact of technology: Many new challenges (Sriram Devulapalli1)are likely to emerge for the fraternity of central banks such as (i) 'e-money' or electronic devices that store monetary value in electronic form; (ii) The balance sheet will affect the extensive use of e-money would be substantially replaced by central bank money; (iii) the capacity of conducting effective Open Market Operations (OMO) also increase in future. (iv) Yet another challenge is the role in crisis prevention in the context of large volume and high speed transactions through complex instruments. (v) The Central banks will have to monitor the growth and pace of financial innovations by the private sector.

\section{G. 5. Retraining and re-skilling of current employees}

Looking at the Global impact of both the automation, and (Rani, 2015) technology more broadly, "We will retrain $60-70 \%$ of our workforce." (RBI, 2018) But some are unsure what they should be retraining people to do, as it is unclear what needs they will have in the future. "In the future of bank, what are you going to do? What are your unique skills? I am still not yet sure where we will need the people in three to five years." Another contribution is when the old jobs disappear, and the new jobs come, there will always be a gap. What will happen in that gap? Is the greatest (Sukanya Sharma, 2018) challenge of Several banks which have to be highlighted as internal mobilityredeploying staff from one department to another-and the potential for and identifying a concept called "reskilling," or (chahal, 2013) training employees to do different jobs. The Re-Skilling exercise is going to be done on the following top priority node; (i) the areas where firms are thinking of alternative options for helping those 
employees. (ii) The cultural implications of wholesale reductions. (iii) We will also offer resume and career counseling services to help people with the transition.

6. The Effectiveness of the Training: A perfect and a careful reassessment of the way that the (Armstrong, 2007). training being implemented for the banks (Rainaye, 2004) in Mumbai will measure that would have be implemented in order to balance and stabilize. (Rida Athar, 2015) As the economy develops, sacrifice ratios in terms of the short-run trade-off between growth and price stability may come down warranting greater stress on price stability in the country. The exchange rate will become a critical factor in the conduct of monetary policy. $\mathbf{1}$. First, the primary interest in financial markets will be sober because of its criticality in the transmission of monetary policy. 2. Second, It develops the conscious effort towards the development of efficient, stable and healthy employee in the private sectors especially. 3. Third, the Government's Securities market which is significant from the point of view of developing a yield among FOREX market, external sector management and gold markets as well. 4. Fourth, It becomes indispensable for the part of the reform in the financial markets such as (A) The employee will equip himself to perform the developmental and regulatory roles effectively. (B) The coordination with other regulators within the country will be sorted out regulatory gaps and overlaps. (C) They will constantly interact with market participants without in any way compromising confidentiality. (D) Liberalization with updated information and market intelligence to assess the prevailing situation and take quick actions will be ultimate result. (E) It will institute arrangements within to (chahal, 2013) improve skills to keep the pace and the skills of market performance.

\section{Conclusion:-}

The research paper has emphasized on the role played by the Training and Development among the Banking employees to face the situations within and between. The first step of why there is a need for Training is found evident and it's been answered through the Identified notified gap between the acquired knowledge and the implementation thereof. The lack of wisdom always brings out an opportunity to provide training and in return it will be an evident that the employee develops as an individual and takes the organization as well.

The private banking sector in Mumbai, Maharashtra, (Chandulal, 2016)India is been located in the prime place of the country. Otherwise called as Manchester of India, the name has been notified because of its business specific so as the growth. Mumbai cannot play a role as one of the several other states in the country, reason that it becomes the Gateway for a Global Business in short. Therefore the Banking sector which is the prime contributor of the business (Arora, 2006)have to be aligned with the Global challenges faced by almost all the business sectors, which includes Bank as a prime sector. The research paper has highlighted the basics of Skill requirement, the Global status of the Banking Sector in view of its prosperity and challenges, The recent developments in the technology has given a big impact to the Bank employees rather than the normal public, as we matter of fact that the COBOL based Banking challenge of $\mathrm{Y} 2 \mathrm{~K}$ has been addressed perfectly with almost no bad impact. In the same manner the training for the Bank employees should take everything which is being mentioned in the paper for their professional growth without fail.

Finally the research has given a great experience of learning and understanding the Banking sector's specific Training needs as compared with the other sectors of the business arena. Well, the training and development session or department functions towards the effective utilization of the employees in the real world. 


\section{Bibliography:-}

1. Abernethy, A. \&. (1992). Advertising. Journal of Retailing68(4) , 398-419.

2. Arora, S. a. (2006). Financial Performance of Indian Banking Sector in Post-Reforms Era. The Indian Journal of Commerce .

3. Banking Governance and Leaership. (April 2018). The future of talent in banking: Workforce evolution in the digital era. EY.

4. British Council. (2017). SKILL REQUIREMENTS AMONG YOUNG PROFESSIONALS IN INDIA. New Delhi: British Council.

5. chahal, A. (2013). A Study of Training Need Analysis Based Training and Development: Effect of Training on Performance by Adopting Development Based Strategy. International Journal of Business and Management Invention, 41-51.

6. Chandulal, G. A. (2016). COMPARATIVE STUDY ON FINANCIAL PERFORMANCE OF PRIVATE SECTOR BANKS. GUJARAT TECHNOLOGICAL UNIVERSITY.

7. Dr.V.Radha. (2012). Banking Theory, Law \& Practice. Chennai: Prasanna publishers \& Distributors.

8. FAROOQI, R. (2017). IMPACT OF INTERNET BANKING SERVICE QUALITY ON CUSTOMER SATISFACTION. Journal of Internet Banking and Commerce , 12-14.

9. (2018). Foreign Banks 2015-18.

10. G. Siva Krishna, S. V. (2012). A study on "e-banking to improve customer base". International Journal of Research and Computational Technology .

11. GOI. (2017-18). Report on Trend and Progress of Banking in India 2017-18. GOI.

12. Hasani, M. H. (2015). WOMEN`S EMPLOYMENT IN OMAN. 12-51.

13. Hudgins, P. S. (2012). Bank Management and Financial Services. New Delh: Tata McGraw Hill.

14. Koundal, D. V. (2012). PERFORMANCE OF INDIAN BANKS IN INDIAN FINANCIAL. International Journal of Social Science \& Interdisciplinary Research, 204-214.

15. P, A. K. (1978). Education and Training system for Banks: A Rejoinder. Prajnan.

16. Pooja Antil, P. A. (2017). A study of Indian banking sector. International Journal of Multidisciplinary Research and Development , 366-368.

17. Rainaye, R. (2004). Training Effectiveness in Public Sector and Private Sector Commercial Banks A MicroLevel Comparative Study. Management \& Change , 49-67.

18. Rani, I. (2015). A STUDY OF IMPACT OF INFORMATION TECHNOLOGY IN INDIAN BNAKING INDUSTRY. Abhinav National Monthly Refereed Journal of Research in Commerce \& Management, 23-28.

19. RBI. (2018). REPORT ON TREND AND PROGRESS OF BANKING IN INDIA . CENTRAL GOVERMENT.

20. Rida Athar, F. M. (2015). Impact of Training on Employee Performance. Journal of Business and Management , 58-67.

21. Sen, A. (1984). Training and Development . Indian Journal of Training and Development , 198-199.

22. SHARMA, M. P. (2010). PAPER ON E-BANKING. CBS E-Journal, Biz $n$ Bytes .

23. Singh, A. K. (2015). An analysis of profitability position of private bank in India. International Journal of Scientific and Research Publications , 1-11.

24. Singh, V. R. (2016). A Study of Non-Performing Assets of Commercial Banks and it's recovery in India. Annual Research Journal of SCMS , 110-115.

25. Sriram Devulapalli1, S. K. (n.d.). Challenges and Opportunities of e-Banking in India. Journal of Business and Management, 56-61.

26. Sukanya Sharma, F. K. (2018). CHANGING PATTERN OF PROMOTION IN INDIAN ORGANIZED RETAIL - REVIEW. International Journal of Management , 55-64.

27. Vershinina, O. (2017). CUSTOMER SATISFACTION IN THE BANKING SECTOR. Oulu University.

28. Institute of Banking \& Finance, Principles and Practice of Banking, McMillan publishers, New Delhi.

29. Muraleedharan D, Modern Banking-Theory and Practice', PHI Learning Pvt. Ltd.

30. Padmalatha Suresh and Justin Paul, "Management of Banking and Financial Services, Pearson, Delhi, 2012. 